\title{
ON SOME PROBLEMS OF THE CREATION AND DEVELOPMENT OF GREEN TECHNOLOGIES IN AZERBAIJAN
}

\author{
Aghamehdi Mehdialiyev \\ Dept. Comp. Technologies at the Government Management \\ Academy of Public Administration \\ Baku, Azerbaijan \\ aga_mehdi@mail.ru
}

\begin{abstract}
In the article, discretions about the great role of green technologies in the life of human-beings are opined as well as green technologies' perspectives and certain success on this field are dealt with.
\end{abstract}

Index Terms - Green technology, green economy, enviromental safety, biocard, electromagnetic radiation, artificial satellite of the earth.

\section{INTRODUCTION}

Effort to formulating knowledge-based community on the basis of global knowledge-based economy is the main aim of knowledge and information-founded society in the modern world. One of the main factors of economic development is environmental safety and green technology refers to the development of IT systems.

The more information technologies' role increases in the life of society, the more importance of necessity to minimize negative ecological change in the production and usage of IT facilities increases. According to the researches of leading research and consulting company Gartner Consulting, $2 \%$ of $\mathrm{CO}_{2}$ gas emission to the air falls to information technologies share.

\author{
Ophelia Mazanova \\ ICT Center \\ Azerbaijan State Economy University \\ Baku, Azerbaijan \\ ofelya2008@gmail.com
}

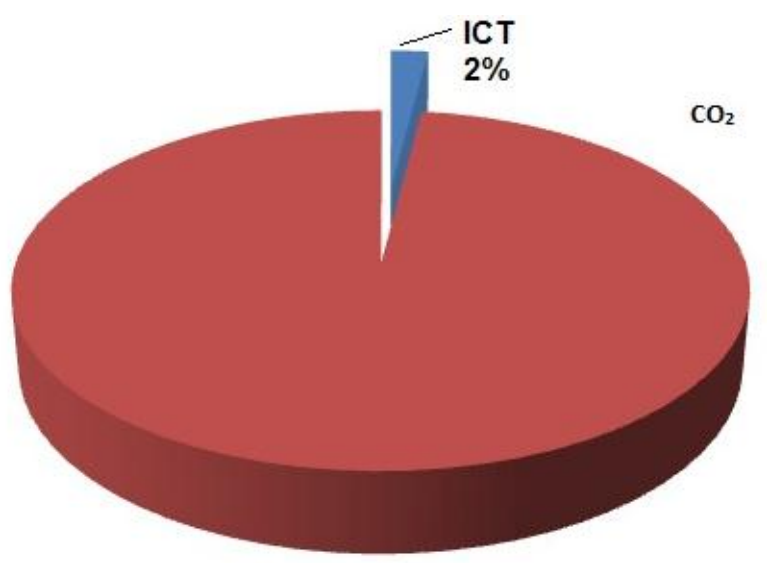

Fig.1. The share of the ICT industry between atmospheric emissions of $\mathrm{CO}_{2}$

As the effectiveness of automobile depends on its usage, the effectiveness of IT also depends on how we use it. It concerns both individual users and huge computer systems as well as companies having enormous database.

According to the prognosis of researchers, the population of the planet will increase up to 9 milliard by 2050 and the great part of them will live in the big cities. Global economy will grow 4 times and the demand for food, fresh water and raw-materials and heating for construction will cause exhaustion of natural resources.

If it is not altered significantly about the demand rule for natural resources of humankind, it will cause mass famine, piercing demand for fresh water and as a result natural resources will wreck swiftly. 
Cities will remain under the slop water, sea level will ascend, fishery will collapse, new desease epidemy will surround the whole earth and red reef will ruin.

The report of authors of research (1300 scholars out of 95 countries) about Millennium Ecosystem Assessment by the order of UNO warns society about the current state of the planet [1].

It is possible to escape from this black scenario by means of investing in health and education spheres, diminishing poverty and paying special attention to the clean technology. As Steven Carpenter noted that, although all these seem incessant regression, but it is a hope history. It must be mentioned that having opportunities for achieving more positive change by 2050 is a good sign.

As professor of Ecology Institute of Stenford, Walter Reed noted that, the standard living has already improved for the most part of the population of planet in the last 50 years: people are long-lived, live in rich, are well fed and can participate in the administration. Such kind of progress costs dear for the state of the natural resources. So, continuation of natural resource's exhaustion (forest, fresh water) specially influences strictly on the poor people life [1].

According to the Walter Reed one of the improvement methods for the future of the planet and population is to use a green technology for the construction of energy-efficient houses and offices.

For the sayings of Carpenter, the number of the buildings built in the XXI century will be equal to the number of the buildings built in the whole history of human-being. Methods on agricultural development must improve, because farm householding is the biggest consumer of the significant change of all the land surface and the fresh water.

Green Tech - means the green technology taken from the English language and it is the increase of effectiveness of energy, enviromental safety and the use of computer sciences in a high level.

Appropriation to innovation technologies, their right location and application make opportunities to guarantee highlevel of trustworthiness for customers and effective work of corporative computer systems [2].

Usage of green technology makes the following opportunities:

1. Saving of assets for purchasing equipments and services

2. Ensuring maximum utilization of IT resources in the enterprise (computer, server, IT-personal, PT)

3. Saving of energy demand, heating excreta and cooling of equipment

4. Increasing of efficiency work indicator through investments

5. Decreasing of the final price of property

6. Saving of server

7. Reduction of monthly operation costs ( energy, telephone bill, salary of service staff, rent)

8. Diminishing the number of malignant wastes to the atmosphere
9. Protection of our planet from global warming and dirtiness

10. Using of environmentally-friendly transport

11. Enviromental safety IT systems

Enviromental safety IT systems help to the enterprises not only develop operations in terms of increasing electric energy tariffs, but also adapt for achieving competition in their own sphere in the business processes [2].

\section{IMPLEMENTED WORKS ON GREEN TECHNOLOGIES AND THEIR DEVELOPMENT PERSPECTIVES}

For the purpose of enlargement of environmentallyfriendly trans- port application in Azerbaijan was created "green bicyclists" that has been operating since September 2008. The main aims are:

$\checkmark$ Achieving of development and construction of factories and roads for environmentally-friendly transport in Azerbaijan (bicycle, tram)

$\checkmark$ Achieving of development of alternative energy sources (solar and wind power and etc) even preparation of necessary equipments in the country and their broad application in Azerbaijan [3].

One of the prominent academicians of Azerbaijan Nizami Suleymanov says in his recent interview: "We learnt that, rue smoke speads positive energy to the enviroment and this smoke transfers into the case of the bus, then to the fuel. In this case, softening process happens in molecular reaction of fuel and during the powdering process small drops appear in hundreds, thounsands instead of one. But when it gets negative energy, then the substance presses". It is simple to check the negative and positive aura of any person. There is negative energy in the radiant of negative-energized person's eye.

Glance of a negative-energized man overdrives any person. Look, this is hoodoo. Why do people burn the rue? When the rue burns, the energetic waves are decomposed around and it influences on the nerve veins of a man, as if reliefs a person. After burning the rue, negative energy is reset and a person comes to himself. This is a proved field".

There are a number of achievements as a result of scientific researches in the green technology sphere in Azerbaijan. One of them is to create a biocard that enables to locate bioenergy in mobile phones BNK-1 TL (Model 1).

A big problem of negative impact of the electromagnetic radiations on the brain cells and human health during using of mobile phones is in the spotlight of the world. It has been determined that electromagnetic radiations of mobile phones cause malignant brain tumour, change in the blood composition, infertility, headache, weaking of immunity and dozens of other diseases. A group of scholars and specialists of ANAS and Azerbaijan Technical University created biocard that is a new product - BNK-1 TL (Model 1) on the basis of the latest achievements of nanotechnology sphere for reducing negative impact of electromagnetic radiations. The production of this output is being realized under the leadership 
of Nizami Suleymanov academician of Azerbaijan National Academy of Activity (ANAA). During the test of the new product in recent years both in our country and abroad has already been known that negative impact of mobile phone's electromagnetic radiations on human health have been reduced.

As a result of this reduction, the volume of energy spent for radiation appearance decreased significantly, for this reason discharge period of phone accumulator has been increased 1,5-3 times. Weaking of electromagnetic radiations lessened the risk of some dangerous diseases significantly.

State Committee for Standardization, Metrology and Patent of the Republic of Azerbaijan gave necessary permission documents for the the same production and sale by confirming BNK-1 TL (Model 1) biocard as an appropriate thing to the mentioned features and considering it as a useful tool for human health. Biocards structure is like this; width 22 , length 42 , thickness 02 millimetre. There is a second version of the biocard - it was considered to watch a computer and a television. That card is a bit bigger and its size is $6 \times 9$ $\mathrm{cm}$. When this card is sticked to the back of the computer, the level of eletromagnetic radiations considerable decreases. It is supposed to do great work on this sphere in Turkey and for this purpose a special company has already been established. The same work is being done in Singapour and Europe.

Some activities are being realized on green technology and smart house projects in International Ecoenergy Academy in Azerbaijan [5].

We can assume green technology world as an innovation and clean world.

Green technology offers:

Saving of assets for purchasing office equipments and its services

Saving of energy consumption and cooling of equipment

1. Ensuring maximum utilization of IT resources in the enterprise (computer, server, IT-personal, PT)

2. Reduction of monthly operation costs ( energy, telephone bill, salary of service staff, rent)

3. Combining of incoherent resources, network and platforms in complex.

4. Innovative and frugal decision: silent computers, green data centre, virtualization systems, "smart offices", energy-qualitative green projects (such as sun, wind and water as an energy source) and so on.

Nowadays development model of our country is accorded to the development tendencies of leading countries. At the same time, formation of the development of science and technology as well as advanced innovation system on the basis of theoretical, methodological and applied sciences is included to the range of strategic purposes of state policy.

"Additional action plan on improvement of enviromental situation in the Republic of Azerbaijan for 2010-2014" was prepared and presented to the Government of Azerbaijan. Application of "green" technologies in ecological problems and enviromental protection specially alternative and renewable energy sources are much more urgent in recent years.

The State Agency on Alternative and Renewable Energy Sources under the Ministry of Industry and Energy was created to solve this problem and its activity is being expanded nowadays.

In spite of possessing a great deal of oil and gas reserves, Azerbaijan's intention to develop alternative energy sources is evident. A number of work that are being implemented to prepare programs for the development of alternative and renewable energy sources by 2020 in The State Agency on Alternative and Renewable Energy Sources under the Ministry of Industry and Energy

It is known that, dynamics of total income and growth rate of ICT sector rapidly increases in our country. So, according to the calculations of worldwide Davos Economic Forum, Azerbaijan's economy was ranked in the 46th place in the world and the first place among CIS countries for its competitiveness [6].

Azerbaijan as a leader state in the region will play an important role in the develoment of "green technology". Mr. Jan Dusic Regional Director of Enviroment Program of UNO certiorated during his speech in round table dedicated to "green technology" in Baku. According to his words, not only the development of "green technology" depend on adopted documents, but also we need people's support. Dusic noted that, "green technology" must recline on sustainable development for improving standard of living and welfare of people. Everybody must understand that development of "green technology" is not only the requirement of legislation, but also the main rule and requirement of modern world. All these work has been started since 2008 in the world. It is possible to achieve important progress by developing "green technology" [7].

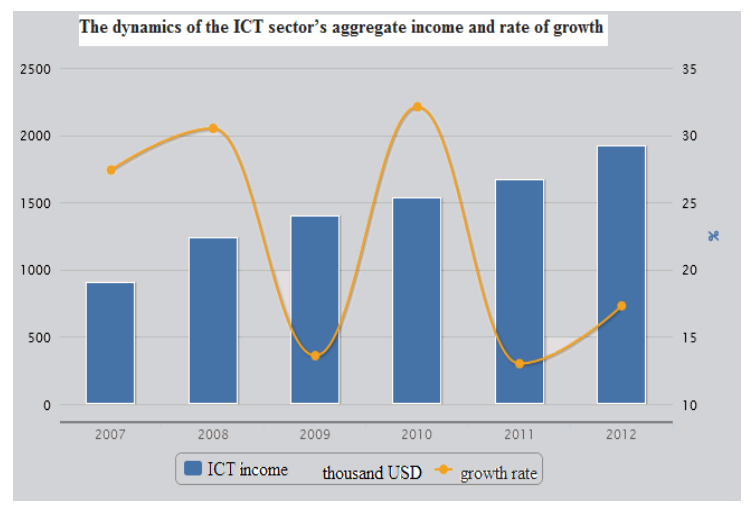

Fig.2. ICT in economy. Source: official web site of the Ministry of Communication and Information Technologies AR

Mahir Aliyev Regional Coordinator of Enviroment Program of UNO on Europe said in his interview to journalists, there is a suitable condition to create "green technology" in Azerbaijan. Work in this direction is highly appreciated by UNO. According to his words, 3 sectors are being explored and learned in this direction right now. These are energy, agriculture and transport sectors. There is an 
important potential for transition to "green economy" in these fields. There are fecund conditions to prefer existed technologies specially in usage of renewable energy sources of energy sector, modern development of agrarian sector and option period of transport sector [8].

We can cite Azerbaijan Diplomatic Academy as an example to green technologies that has been using its achievements since 2007 in Azerbaijan. In a short time, ADA was moved to a new campus in September 2012. The campus uses alternative energy sources by locating special equipments in a particular place. One of the attracting point in ADA is its modern library system. We can consider ADA's library as a small-sized model of the Library of Congress formed by the order of American President John Adams in 1800. There are 35000 books, 300000 electronic books, journals, borchure and so on in ADA's library now. Online book kiosks are placed on every floor of the library. It is used $3 \mathrm{M}^{\mathrm{TM}}$ equipment labelled RFID in the library. $3 \mathrm{M}^{\mathrm{TM}}$ equipments are the security doors that ensure the security of the library fund. It is possible to implement certain operations to provide the acceleration processes of books exchange (take and give back), preventing of stealing and changing books, making easy of stock operations and automatic registration processes

Besides this, new terminal is used through $3 \mathrm{MselfChek}^{\mathrm{TM}}$ system. This system enables to register a number of books at the same time. Everybody can do it by registering books. Each person takes ID code in registration. There is an opportunity to translate the menu into different languages. 3 MselfChek ${ }^{\mathrm{TM}}$ system works on several themes of the library fund at the same time. It also reads RFID labels as a stroke code. ADA Library where alternative energy sources are applied and automated library supported by $3 \mathrm{M}^{\mathrm{TM}}$ technologies use Millenium information system. Used papers are gathered in a special boxes in Azerbaijan Diplomatic Academy and are sent to Green organization to reproduce.

Nowadays the State Agency on Alternative and Renewable Energy Sources under the Ministry of Industry and Energy is implementing a range of work to prepare a program on the development of alternative and renewable energy sources by 2020.

Ilham Aliyev President of the Republic of Azerbaijan stated these words about the ecological situation in our country: "It is known that, "green technology" not only enables waste to reduce, but also decreases it to zero level. We take serious measures about enviromental safety.

Firstly, being unpleasant ecological situation shouldn't impact on people. "Fresh air", "Fresh water", "Fresh environment" - we do all these things to protect human health [8].

For this purpose a number of big projects like "7 dağ" (Seven mountians), "Temiz Sheher" ("Clean city) and "Ag Sheher" (White city) have already been started in Nargin island in our country.

Building a resort complex in "Boyuk Zire" (former Nargin) island around Baku is planned. A resort will contain of complexes in the figure of 7 mountain crests of Azerbaijan. There will also be installed 300 villas, a golf club, beach complex in the island. The sun beam will be the energy source of the resort. Ministry of Tourism and Culture has prepared several projects concerning of creating tourism center in Nargin island. According to the plan, electric energy will be gotten on the account of solar, wind and water energy in the island. There will be built electric stations for this purpose. The main aim is to prevent throwing toxic garbage to the environement and making the condition available for ecotourism in the island.

Area of Nargin island is close to 1 million sq/m. There will be built dwellings for people in complexes consisting of resorts and entertainment centres. There also will be created suitable conditions for 10 thousand inhabitants meeting the modern requirement and comfort will be ensured $100 \%$.

Automobiles motion to the island will be prohibited to protect air. It will help to protect fesh air layer in the area. Helicopters will run directly to the island from the International Airport. Besides this, taxi boats and ships on the coastline will service to keep a contact between Nargin island and the city. It will be created on the basis of 7 the most famous mountains image in the island. Thus, resort will resemble 7 mountains of Azerbaijan outside. The project that will be realised for 6 years has no analogue yet in the world.

"Clean Gala" project is being implemented by "Clean City" LTD to install proper waste management system as a pilot project in Gala settlement of Baku by the intiative of Haydar Aliyev Fund. The purpose of the project is to organize scavenge and transport of the waste materials in Gala settlement, as well to ensure their utilization according to the modern standards. More than 120 waste squares have been installed for scanvenge in the area and organized regular transportation of waste materials in the framework of the project.

Besides this, waste containers are regular washed and disinfected according to the sanitary and hygienic norms. All tehniques have already been joined to GPS navigation system in the settlement that, this enables to follow and manage the technics where it works in any time.

Assortation of wastes on organic and inorganic garbages are applied for the purpose of proper and effective implementation of waste management. The settlement has been provided by two-colored containers; green and blue throughout the settlement. A number of agitations are implemented among the inhabitants to ensure active participation of the settlement inhabitants during the assortation process. Assortation of wastes and remanufacturing cause enlargement of cheap raw-materials, save of energy and natural resources.

"Clean City" second carbon credit project has been registered in the UNO. Carbon credit project for keeping biogases in Balakhani range of Baku according to the UNO Clean Development Mechanism by "Clean City" LTD has been registered succesfully in the framework of Climate Change Convention of the UNO.

The first project presented by "Clean City" LTD connects with activity of Waste Burning Factory. Alternative energy is got in the results of burning wastes in the project framework. 
In the end of the implementation of these two projects, not only shall we render properly the wastes harmless but also we shall get alternative energy. It will also be possible to prevent negative impacts of it for human health and environment.

Monitoring of the project will be regularly fulfilled by independent auditors appointed by the UNO. "Waste Calculator" project has started in Baku too. "Waste Calculator" project is the real innovation for our country that is implementing in the framework of the long-term enlightenment program on waste reduction by "Clean City" LTD.

There will be created the modernist and huge residential areas according to the new development project on the "Baku White City" project in the polluted areas with oil and oil wastes in Baku. There will be built administrative buildings, different trade centers, parks and boulevard that will consolidate new residential center with the sea.

Social infrastructure will be built in the level of the modernist requirements in "Baku White City". The official website of the project presents information in three languages: http://www.bakuwhitecity.com

Today, information resources about the duties and plans of Baku White City town-building project is presenting to the large auditorium of internet users.

Azerbaijan use widely the application of new technology right now. For instance, we can show launched satellite into orbit in the beginning of Fbruary 2013. Sputnik will be directed to the regions of CIS, Asia, The Near East and Africa in the near future. We assume that, launch of "Azerspace-1" artificial satellite of the earth will give a great push for the development of green economy.

Realization of these projects that takes people to the bright future will positive impact on the life of inhabitants of the country. At the same time, it will give a push to the rapid development of green economy in Azerbaijan.

\section{REFERENCES}

[1].Usha Lee Makfarling. Industrial sheets, 1-2 February 2006."Green"

technology the main condition for the bright future of mankind. ["Зеленые" технологии главное условие светлого будущего человечества. Промышленные ведомости]

[2].http://www.sib.com.ua/arhiv...6/.statia_6_8_2009.htm

[3].http://www.veloklub.com/

[4].F.Aliyev, A.Mehdialiyev, N.Mammadov, F.Aliyev. Development

of mathematical model of intellectual building in Baku city. Proceedings of the second international conference "Problems of cybernetics and informatics", PCI'2008, deducated to the $50^{\text {th }}$ Anniversary of the ICT in Azerbaijan, Volume I

[5].http://www.maqazin.com/xeberler/787-az601rbaycanl305aliml601rin-k601351fi-mobil-telefonlarda-bioenerjiyerl601351diril601c601k.html

[6].http://www.mincom.gov.az/charts-az-AZ/ikt-iqtisadiyyatda/

[7.http://www.milli.az/news/society/151336.html

[8].http://www. eco.gov.az 